\title{
Effect of respiratory virus infections including rhinovirus on clinical status in cystic fibrosis
}

\author{
A R Smyth, R L Smyth, C Y W Tong, C A Hart, D P Heaf
}

\begin{abstract}
One hundred and eight patients with cystic fibrosis were investigated over one year to determine whether an association existed between rhinovirus or other respiratory virus infection and clinical status. Forced expiratory volume in one second $\left(F E V_{1}\right)$, forced vital capacity (FVC), Shwachman score, ChrispinNorman chest radiograph score, and percentage weight for height were recorded at the beginning and end of the study; days of intravenous antibiotics were noted. Nasopharyngeal aspirates were taken for viral studies during respiratory exacerbations. Serum was collected at enrolment and 2-6 weeks after each respiratory exacerbation. One hundred and fifty seven exacerbations occurred in 76 patients. Respiratory virus infection was detected in 44 exacerbations and rhinovirus was present in $16 \%$ (25/157) of exacerbations. Patients with one or more respiratory virus infections were compared with those who had none. When all respiratory virus infections were considered, patients had a significantly greater deterioration in Shwachman score and received significantly more days of intravenous antibiotics. When rhinovirus was considered separately, patients received significantly more days of intravenous antibiotics, but showed no deterioration in clinical status. However, patients infected with another respiratory virus had a significant decline in $F_{1}$, with trends towards significance for decline in FVC and Shwachman score. (Arch Dis Child 1995; 73: 117-120)
\end{abstract}

Keywords: cystic fibrosis, rhinovirus, respiratory virus.

and University, Medical Microbiology,

Royal Liverpool

University Hospital

A R Smyth

R L Smyth

University Department of Medical

Microbiology, Royal

Liverpool University

Hospital

C Y W Tong

C A Hart

Respiratory Unit, Royal Liverpool Children's Hospital D P Heaf

Correspondence and reprint requests to: Dr R L Smyth, Respiratory Unit, Royal Liverpool Children's Hospital, Alder Hey, Liverpool L12 2AP.

Accepted 18 April 1995

Although, in recent years, there have been improvements in the life expectancy of patients with cystic fibrosis, most die in early adult life from respiratory failure. ${ }^{1}$ Despite vigorous conventional management with antibiotics and physiotherapy, pulmonary function undergoes a steady decline in cystic fibrosis. Kerem et al estimated that when the forced expiratory volume in one second $\left(\mathrm{FEV}_{1}\right)$ falls below 30\% predicted then that patient has a $50 \%$ chance of dying within two years. ${ }^{2}$ Two prospective studies that have investigated the role of respiratory virus infection in this decline in pulmonary function have led to differing results. Wang and colleagues found that the annual incidence of virus infection was correlated with deterioration in several important clinical indices, including pulmonary function. ${ }^{3}$ In contrast, Ramsey and colleagues, in a smaller study, found that those patients with a higher rate of respiratory virus infection were younger and their clinical indices deteriorated less than patients who had fewer such infections. ${ }^{4}$

This study was designed to investigate whether an association was present between respiratory virus infection and clinical indices in a large cohort of cystic fibrosis patients, over a one year period. By using the sensitive polymerase chain reaction (PCR) to detect rhinovirus we hoped to assess, more accurately than had been done previously, whether infection with this upper respiratory tract pathogen was independently associated with deterioration in these clinical indices.

\section{Patients and methods}

PATIENTS

The study was conducted between April 1992 and April 1993 in the cystic fibrosis clinic of the Royal Liverpool Children's Hospital Alder Hey. All patients under 20 years, and living within 15 miles of the hospital, were eligible to take part. Baseline serum specimens were collected during the first six months of the study (1 April-30 September 1992). During this 'run in period', blood was taken only from those patients who had not had a respiratory exacerbation in the preceding two months. From 1 October 1992-31 March 1993 patients were asked to attend when they had coryzal symptoms or a worsening cough. During these visits, a nasopharyngeal aspirate was collected for viral culture and direct immunofluorescence. At 2-6 weeks after each visit a convalescent serum specimen was collected.

PULMONARY FUNCTION TESTS AND CLINICAL SCORES
$\mathrm{FEV}_{1}$, forced vital capacity (FVC), Shwachman score, ${ }^{5}$ Chrispin-Norman chest radiograph score, ${ }^{6}$ and percentage weight for height were recorded at the beginning and end of the study. In each case the 1992 value was subtracted from the 1993 value to give the change over the study period, which was used as the clinical end point. The number of days of intravenous antibiotics given to each patient during the study period was also used as a clinical end point. $\mathrm{FEV}_{1}$ and FVC were measured using a portable spirometer (Micro Medical Ltd) and the measurements were expressed as a percentage of predicted for height and gender, using the values of Polgar and Promadhat. ${ }^{7}$ Chrispin-Norman scores 
Table 1 Comparative results of viral diagnostic methods used

\begin{tabular}{|c|c|c|c|c|}
\hline Virus type & Serology & $P C R$ & Tissue culture & Immunofluorescence \\
\hline $\begin{array}{l}\text { Parainfluenza (type } 1 \text { ) } \\
\text { Influenza (A and B) } \\
\text { Adenovirus } \\
\text { Respiratory syncytial virus } \\
M \text { pneumoniae } \\
\text { Rhinovirus }\end{array}$ & $\begin{array}{l}5 \\
5 \\
4 \\
4 \\
1 \\
-\end{array}$ & $\begin{array}{l}- \\
- \\
- \\
- \\
- \\
25\end{array}$ & $\begin{array}{l}4 \\
0 \\
0 \\
0 \\
0 \\
-\end{array}$ & $\begin{array}{l}0 \\
1 \\
0 \\
0 \\
0 \\
-\end{array}$ \\
\hline \multirow[t]{2}{*}{ Total } & 19 & 25 & 4 & 1 \\
\hline & $\begin{array}{c}\text { tal viral } \\
\text { diagnos }\end{array}$ & ions & & \\
\hline
\end{tabular}

were recorded by two assessors (DPH and RLS) who were not aware of whether patients were in the viral or non-viral groups.

\section{DEFINITIONS}

Chronic Pseudomonas aeruginosa infection was defined as the presence of $P$ aeruginosa in three sputum specimens over a one year period, before the start of the study, as proposed by Cordon et al. ${ }^{8} \mathrm{~A}$ similar definition was used for chronic Pseudomonas cepacia infection.

\section{SAMPLE COLLECTION AND PREPARATION}

A nasopharyngeal aspirate was taken from each patient using a portable suction unit (Laerdal Ltd), connected to a mucus trap (Stericaine Ltd), with a 6 French gauge suction catheter (Sherwood Medical). The collecting system was flushed with $0.2 \mathrm{ml}$ of sterile $0.9 \%$ saline to remove any mucus adhering to the suction catheter. Each sample was stored at $4^{\circ} \mathrm{C}$ for a maximum of 12 hours, mixed thoroughly with $2 \mathrm{ml}$ of minimal essential medium (MEM, Gibco), and centrifuged at $2000 \times g$ for five minutes. Immunofluorescence slides were prepared from the cell pellet and the remaining pellet and supernatant were frozen at $-70^{\circ} \mathrm{C}$.

\section{LABORATORY METHODS}

Immunofluorescence slides were examined using fluorescein labelled monoclonal antibodies (Dako Diagnostics Ltd) to the following respiratory viruses: parainfluenza types 1-3, respiratory syncytial virus, adenovirus, and influenza A and B. Both baseline and convalescent serum specimens were examined using the complement fixation test for antibodies to the respiratory viruses mentioned above, with the addition of Mycoplasma pneumoniae. Serology was said to be positive if there was a fourfold rise in titre between any two specimens. Where this occurred, viral culture was performed retrospectively on the corresponding nasopharyngeal aspirates. The supernatant frozen at $-70^{\circ} \mathrm{C}$ was inoculated on to an appropriate viral culture system: (LLCMK2 cells for parainfluenza, MA104 for respiratory syncytial virus, vero for adenovirus, and embryonated hens' eggs for influenza). Positive cultures were identified by cytopathic effect where appropriate and direct immunofluorescence in all cases.

A seminested, reverse transcriptase PCR was used with each nasopharyngeal aspirate to detect rhinovirus ${ }^{9}$; RNA was extracted using the method of Chomczynski and Sacchi. ${ }^{10} \mathrm{~A}$ positive control sample of human rhinovirus grown in tissue culture, and a negative control sample of MEM, were included in each batch. The finding of a 202 base pair amplification product on ethidium bromide gel was taken to indicate human rhinovirus infection.

\section{STATISTICS}

Statistical analysis was by the Mann-Whitney $\mathrm{U}$ test for non-parametric data and the $\chi^{2}$ test, using the Arcus Pro-stat statistics package.

\section{Results}

One hundred and eight patients were recruited. Median age was $7 \cdot 9$ years (range 2 months -20 years) and $46 / 108(43 \%)$ were female. $P$ aeruginosa colonisation was present in $68 / 108(63 \%)$ patients and $P$ cepacia in $8 / 68$ $(12 \%)$ of these. Exacerbations occurred in 76 patients on 157 occasions. Respiratory virus infection occurred in 33 patients on 44 occasions. The respiratory viruses identified and the comparative results of different diagnostic methods are shown in table 1 .

Those patients who had one or more respiratory virus infections during the study period $(n=33)$ were compared with those who had none $(n=75)$. There was no significant difference between age, sex, pseudomonas status, or baseline clinical end points in the two groups. Table 2 shows the results of statistical comparison of the viral and non-viral groups. Patients who had one or more viral infections during the study period had a significantly greater decline in Shwachman score and were prescribed significantly more days of intravenous antibiotics. There was a trend towards a decline in $\mathrm{FEV}_{1}$ that just failed to reach statistical significance. There was no significant difference between the groups with respect to FVC, weight, or Chrispin-Norman score.

In order to distinguish the effects of upper and lower respiratory tract pathogens a subgroup analysis was performed, comparing the non-viral group $(n=75)$ separately with the

Table 2 Clinical end points in the viral $(n=33)$ and non-viral $(n=75)$ groups

\begin{tabular}{|c|c|c|c|c|c|}
\hline \multirow[b]{2}{*}{ Clinical end point } & \multirow{2}{*}{$\begin{array}{l}\text { Median } \\
\text { difference }\end{array}$} & \multicolumn{2}{|l|}{ Range of values } & \multirow[b]{2}{*}{ p Value } & \multirow{2}{*}{$\begin{array}{l}\text { Confidence } \\
\text { interval }\end{array}$} \\
\hline & & Viral group & Non-viral group & & \\
\hline $\begin{array}{l}\text { Days of intravenous antibiotics } \\
\text { Shwachman score } \\
\text { FEV } 1 \% \text { of predicted) } \\
\text { FVC (\% of predicted) } \\
\text { Weight (\% of ideal for height) } \\
\text { Chrispin-Norman score }\end{array}$ & $\begin{array}{l}14 \\
-5 \\
-6 \cdot 13 \\
-5 \cdot 10 \\
-1 \\
0\end{array}$ & $\begin{array}{l}0 \text { to } 84 \\
-20 \text { to } 15 \\
-36 \cdot 4 \text { to } 34 \cdot 84 \\
-23 \cdot 9 \text { to } 42 \cdot 2 \\
-14 \text { to } 10 \\
-4 \text { to } 5\end{array}$ & $\begin{array}{l}0 \text { to } 216 \\
-25 \text { to } 20 \\
-47 \cdot 4 \text { to } 25 \cdot 63 \\
-30 \cdot 9 \text { to } 27 \cdot 0 \\
-11 \text { to } 22 \\
-5 \text { to } 7\end{array}$ & $\begin{array}{l}0.011 \\
0.037 \\
0 \cdot 055 \\
0 \cdot 162 \\
0 \cdot 468 \\
0 \cdot 681\end{array}$ & $\begin{array}{l}0 \text { to } 14 \\
-5 \text { to } 0 \\
-12 \cdot 8 \text { to } 0 \cdot 1 \\
-12 \cdot 0 \text { to } 2 \cdot 1 \\
-3 \text { to } 1 \\
-1 \text { to } 1\end{array}$ \\
\hline
\end{tabular}


Table 3 Clinical end points in other virus ( $n=13)$ and rhinovirus $(n=15)$ groups v non-viral group $(n=75)$

\begin{tabular}{|c|c|c|c|c|c|}
\hline \multirow[b]{2}{*}{ Clinical end point } & \multirow{2}{*}{$\begin{array}{l}\text { Median } \\
\text { difference }\end{array}$} & \multicolumn{2}{|l|}{ Range of values } & \multirow[b]{2}{*}{$p$ Value } & \multirow{2}{*}{$\begin{array}{l}\text { Confidence } \\
\text { interval }\end{array}$} \\
\hline & & Viral group & Non-viral group & & \\
\hline $\begin{array}{l}\text { Other virus and } M \text { pneumoniae } \\
\text { FEV }(\% \text { of predicted) } \\
\text { FVC (\% of predicted) } \\
\text { Shwachman score }\end{array}$ & $\begin{array}{l}-11 \cdot 5 \\
-9 \cdot 13 \\
-5\end{array}$ & $\begin{array}{l}-21.5 \text { to }-1.01 \\
-23.9 \text { to } 9.59 \\
-15 \text { to } 5\end{array}$ & $\begin{array}{l}-47 \cdot 4 \text { to } 25 \cdot 63 \\
-30 \cdot 9 \text { to } 27 \cdot 0 \\
-25 \text { to } 20\end{array}$ & $\begin{array}{l}0.005 \\
0.068 \\
0.085\end{array}$ & $\begin{array}{l}-18 \cdot 1 \text { to }-3 \\
-18 \cdot 1 \text { to } 0.9 \\
-5 \text { to } 0\end{array}$ \\
\hline $\begin{array}{l}\text { Rhinovirus } \\
\text { Days of intravenous antibiotics }\end{array}$ & 14 & 0 to 84 & 0 to 216 & 0.005 & 5 to 28 \\
\hline
\end{tabular}

rhinovirus group $(n=15)$ and the 'other virus' group $(n=13)$. Five patients, who experienced infections with both rhinovirus and another virus, were excluded from this analysis. There was no significant difference between the virus subgroups and the non-viral group in age, pseudomonas status, or baseline clinical indices. However, there were significantly more boys $(12 / 15)$ in the rhinovirus group than in the non-viral group $(35 / 75, p=0.042)$. As table 3 shows, there was a statistically significant decline in $\mathrm{FEV}_{1}$ in the other virus group compared with the non-viral group, with trends towards significance for decline in FVC and Shwachman score. When the rhinovirus group was compared with the non-viral group, those patients in the rhinovirus group required significantly more days of intravenous antibiotics but there was no significant difference between these groups for the remaining variables.

\section{Discussion}

We have shown in a large cohort of patients with cystic fibrosis, studied over a one year period, that respiratory virus infection was associated with a decline in Shwachman score and an increased number of days of intravenous antibiotics prescribed. When rhinovirus and other virus infections were analysed separately, there was a significant association between other virus infections and decline in $\mathrm{FEV}_{1}$ and a trend towards significance in the decline in FVC. In contrast, when compared with the non-viral group, rhinovirus infections were not associated with a decline in any of the clinical end points, apart from an increased number of days of intravenous antibiotics. This suggests that rhinovirus infection may produce symptoms which prompt the clinician to start intravenous antibiotics but that the infection has no long term effect on lung function.

Wang et al studied 49 patients with cystic fibrosis over a two year period, and found an association between respiratory viral infection and decline in Shwachman score, percentage ideal weight for height, $\mathrm{FEV}_{1}, \mathrm{FVC}$, and the frequency and duration of hospitalisations from respiratory exacerbations. ${ }^{3}$ Ramsey et al studied 15 patients with cystic fibrosis over two years and were unable to demonstrate any adverse effect of respiratory viral infection on pulmonary function. ${ }^{4}$ However, this latter study was limited by the small number of patients enrolled and the exclusion of patients under 5 years in whom the incidence of viral infection would be expected to be higher.

Our study is the first to use PCR to examine the role of rhinovirus in respiratory exacerbations of cystic fibrosis. We have shown that rhinovirus is an important precipitant of these exacerbations, being present in $16 \%$ of episodes. The seminested PCR used is five times more sensitive than tissue culture techniques. ${ }^{9}$ In the study of Wang et al all viral diagnoses were made by serology. ${ }^{3}$ Diagnosis of rhinovirus infection was therefore impossible, due to the large number of rhinovirus serotypes. In the study of Ramsey et al approximately one third of viral diagnoses were made by tissue culture and $22 \%$ of viruses identified were rhinovirus. ${ }^{4}$ This is substantially less than the figure of $57 \%$ identified with the more sensitive PCR technique in our study. The inability of the study by Wang et al to detect rhinovirus may account for the differing results between their study and that of Ramsey et al. Further evidence for this is the similarity between Wang et al's results and the results that we obtained for the other virus, or lower respiratory tract pathogen, group compared with the non-viral group.

Studies of the role of respiratory viral infection in asthma have shown rates of rhinovirus isolation of $33 \%$ in adults ${ }^{11}$ and $50 \%$ in children, ${ }^{12}$ using PCR techniques. The smaller proportion of exacerbations of cystic fibrosis in which rhinovirus can be isolated is not surprising in view of the major role which bacterial flora, present transiently or chronically in the respiratory tract, are known to have in these exacerbations.

The low detection rates by tissue culture and immunofluorescence was disappointing. In most published studies on respiratory viral infections in cystic fibrosis, the majority, and in some cases all, of the infections were diagnosed by serology. ${ }^{341314}$ Authors have commented on the difficulty in isolating viruses by tissue culture from patients with cystic fibrosis, ${ }^{3} 13$ which may be related to the thick, mucoid secretions obtained from their airways. This may also play a part in impairing detection by immunofluorescence.

The decline in lung function observed in patients infected with lower respiratory tract pathogens, may be due to a direct effect of the virus on the respiratory tract. Persistently impaired lung function has been found in asymptomatic children 10 years after bronchiolitis. ${ }^{15}$ Alternatively, a synergy may exist between respiratory virus infection and bacterial organisms that are present transiently or chronically in the lungs of cystic fibrosis patients. Petersen and colleagues found that respiratory syncytial virus infection was more frequently associated with acute exacerbations 
in patients who acquired chronic $P$ aeruginosa infection during their study. ${ }^{13}$

In conclusion, we have demonstrated that lower respiratory virus infection is associated with a decline in lung function in cystic fibrosis. Rhinovirus infection, when considered separately, appears to follow a more benign course, but is associated with greater use of intravenous antibiotics.

1 Britton JR. Effects of social class, sex and region of residence on age at death from cystic fibrosis. $B M \Im$ 1989; 298: 483-7.

2 Kerem E, Reisman J, Corey M, Canny GJ, Levinson H. Prediction of mortality in patients with cystic fibrosis. N Engl F Med 1992; 326: 1187-91.

3 Wang EEL, Prober CG, Manson B, Corey M, Levinson $\mathrm{H}$. Association of respiratory viral infection with pulmonary deterioration in patients with cystic fibrosis. $N$ Engl $7 \mathrm{Med}$ 1984; 311: 1653-8.

4 Ramsey BW, Gore EJ, Smith AL, Cooney MK, Redding GJ, Foy $\mathrm{H}$. The effect of respiratory viral infections on patients with cystic fibrosis. Am $\mathcal{f}$ Dis Child 1989; 143: 662-8.

5 Shwachman H, Kulczycki LL. Long-term study of one hundred five patients with cystic fibrosis. Am $\mathcal{J}$ Dis Child 1958; 96: 6-15.
6 Chrispin AR, Norman AP. The systematic evaluation of the chest radiograph in cystic fibrosis. Pediatr Radiol 1974; 2 101-6.

7 Polgar G, Promadhat V. Pulmonary function testing in children: techniques and standards. Philadelphia: Saunders, 1971.

8 Cordon SM, Elborn JS, Rayner RJ, Hiller EJ, Shale DJ. IgG antibodies in early Pseudomonas aeruginosa infection in cystic fibrosis. Arch Dis Child 1992; 67: 737-40.

9 Ireland DC, Kent J, Nicholson KG. Improved detection of rhinovirus in nasal and throat swabs by semi-nested of rhinovirus in nasal and throat swabs
RT-PCR. $\mathcal{M}$ Med Virol 1993; 40: 96-101.

10 Chomczynski P, Sacchi N. Single step method of RNA isolation by acid guanidinium thiocyanate-phenolisolation by acid guanidinium thiocyanate-phenolchloroform extraction. Anal Biochem 1987; 162: 156-9. exacerbations of asthma in adults. BMF 1993; 307: 982-6.

12 Johnston SL, Pattermore PK, Sanderson G, et al. Role of Johnston SL, Pattermore PK, Sanderson G, et al. Role of
virus infections in exacerbations in children with recurrent virus infections in exacerbations in children
wheeze or cough. Thorax 1993; 48: 1055.

13 Petersen NT, Hoiby N, Mordhorst CH, Lind K, Flensborg EW, Bruun B. Respiratory infections in cystic fibrosis patients caused by virus, chlamydia and mycoplasma - possible synergism with Pseudomonas aeruginosa. Acta Paediatr Scand 1981; 70: 623-9.

14 Stroobant J. Viral infection in cystic fibrosis. $f R$ Soc Med 1986; 79 (suppl 12): 19-22.

15 Kattan M, Keens TJ, Lapierre JG, Levinson H, Bryan C, Reilly BJ. Pulmonary function abnormalities in symptomfree children after bronchiolitis. Pediatrics 1977; 59: 683-8. 